\title{
Pengaruh Pendekatan Kontekstual pada Pembelajaran Jarak Jauh terhadap Kemampuan Komunikasi Matematis Siswa SMA Negeri 1 Depok
}

\author{
Fauzi Ramadhan ${ }^{1, a)}$, Tri Murdiyanto ${ }^{2, b)}$, Siti Rohmah Rohimah ${ }^{3, c)}$ \\ ${ }^{1,2,3}$ Universitas Negeri Jakarta
}

Email: a)fauziramadhan_3115160528@mhs.unj.ac.id

\begin{abstract}
Abstrak
Penelitian ini bertujuan untuk mengetahui apakah terdapat pengaruh pendekatan kontekstual pada pembelajaran jarak jauh terhadap kemampuan komunikasi matematis siswa SMA Negeri 1 Depok. Metode penelitian yang digunakan adalah metode eksperimen semu (quasi experiment). Instrumen penelitian yang digunakan adalah instrumen tes kemampuan komunikasi matematis berupa 7 soal uraian yang telah dinyatakan valid. Populasi target penelitian adalah seluruh siswa SMA Negeri 1 Depok. Populasi terjangkau penelitian adalah siswa kelas X SMA Negeri 1 Depok. Teknik pengambilan sampel menggunakan Two Stage Sampling, yaitu Purposive Sampling dan Cluster Random Sampling. Berdasarkan hasil pengujian prasyarat analisis data setelah perlakuan, hasil tes kemampuan komunikasi matematis kelas eksperimen dan kontrol berdistribusi normal dan homogen. Pengujian hipotesis statistik Uji-t dengan taraf signifikansi $\alpha=0,05$, diperoleh $t_{\text {hitung }}=6,753$ dan $t_{\text {tabel }}=1,668$. Nilai $t_{\text {hitung }}$ $>t_{\text {tabel }}$ sehingga $H_{0}$ ditolak dan diperoleh kesimpulan bahwa rata-rata skor tes kemampuan komunikasi matematis siswa kelas eksperimen lebih tinggi dari kelas kontrol. Besar pengaruh pendekatan kontekstual pada pembelajaran jarak jauh terhadap kemampuan komunikasi matematis siswa SMA Negeri 1 Depok adalah $d=1,6$ dengan presentasi $94,5 \%$ dan berada pada kategori besar. Hal ini menunjukkan bahwa terdapat pengaruh pendekatan kontekstual pada pembelajaran jarak jauh terhadap kemampuan komunikasi matematis siswa SMA Negeri 1 Depok.
\end{abstract}

Kata Kunci: Pendekatan Kontekstual, Pembelajaran Jarak Jauh, Kemampuan Komunikasi Matematis

\section{PENDAHULUAN}

Pendidikan merupakan komponen fundamental bagi suatu bangsa. Pentingnya pendidikan bagi Bangsa Indonesia ditunjukkan dengan diterbitkannya aturan berupa UU No. 20 Tahun 2003 tentang Sistem Pendidikan Nasional. Pada pasal 5 Ayat (1), dinyatakan bahwa "Setiap warga negara mempunyai hak yang sama untuk memperoleh pendidikan yang bermutu". Pendidikan yang bermutu dapat diwujudkan dengan memperhatikan berlangsungnya pembelajaran di dalam kelas, salah satunya pada pelajaranpelajaran mendasar seperti matematika.

Menurut Suriasumantri (2015), matematika adalah ilmu yang mempelajari bilangan dan memiliki dampak yang besar terhadap ilmu lainnya. Dengan matematika, peradaban berkembang pesat karena tidak berhenti pada tahap kualitatif saja. Suatu ilmu apapun, akan sampai pada titik kuantitatif yang membutuhkan matematika. Dalam ilmu pengetahuan, matematika memungkinkan untuk melatih penalaran sehingga dapat dikatakan matematika sangat penting dalam kehidupan. Pembelajaran 
matematika di dalam kelas perlu diperhatikan karena akan banyak berdampak ke dalam dunia pendidikan.

Pembelajaran matematika di dalam kelas harus mampu mengasah kemampuan-kemampuan matematika siswa. National Council of Teachers of Mathematics (NCTM) (2000) menetapkan lima standar kemampuan matematis yang harus dimiliki oleh siswa, yaitu kemampuan pemecahan masalah (problem solving), kemampuan komunikasi (communication), kemampuan koneksi (connection), kemampuan penalaran (reasoning), dan kemampuan representasi (representation). Berdasarkan kelima standar kemampuan matematis tersebut, dapat diketahui bahwa kemampuan komunikasi adalah bagian dari kemampuan matematika dalam diri siswa yang harus dikembangkan oleh guru melalui pembelajaran di dalam kelas.

Mahmud dan Hartono (2014) mengatakan bahwa komunikasi matematis merupakan kemampuan siswa untuk menyatakan dan menerjemahkan gagasan matematis dengan mengucapkan, menuliskan, atau mendemonstrasikan persoalan yang ada dalam matematika. Penguasaan kemampuan komunikasi yang baik akan menjadikan gagasan-gagasan matematis siswa mampu digambarkan, diperbaiki, didiskusikan, dan dikembangkan. Kemampuan komunikasi dalam matematika dinilai sangat penting sebagaimana dikatakan Fatmasuci (2017) bahwa kemampuan komunikasi merupakan kemampuan awal yang dibutuhkan untuk pengembangan matematika.

National Council of Teachers of Mathematics (NCTM) (2000) mengungkapkan bahwa kemampuan komunikasi matematis perlu menjadi perhatian yang utama dalam pembelajaran matematika. Hal itu karena kemampuan komunikasi berpengaruh terhadap kemampuan siswa dalam mengembangkan cara berpikir matematis, menyampaikan gagasan matematis, menalar dan mengevaluasi strategi, serta dapat mengeksplorasi ide-ide matematika. Baroody (dalam Azmi, 2017) mengemukakan sedikitnya ada dua alasan yang menjadikan kemampuan komunikasi adalah hal yang penting dalam pembelajaran matematika. Pertama, matematika bukan hanya sekadar alat bantu berpikir, menemukan pola atau menyelesaikan masalah melainkan juga sebagai alat yang dapat mengkomunikasikan berbagai ide dengan ringkas dan jelas. Kedua, kemampuan komunikasi memungkinkan pembelajaran matematika sebagai aktivitas sosial yang terdiri dari interaksi antara siswa dengan siswa, dan antara siswa dengan guru.

Berdasarkan penjabaran di atas dapat disimpulkan bahwa kemampuan komunikasi merupakan bagian penting yang harus diperhatikan dalam pembelajaran matematika. Namun, fakta yang ada menunjukkan kemampuan komunikasi siswa masih rendah. Hal ini dibuktikan dari hasil survei dalam bidang matematika yang dilakukan oleh Program for International Student Assesment (PISA). Survei tersebut mengukur kemampuan siswa dalam memecahkan masalah matematis yang terdiri dari mengenali dan menganalisis masalah, memformulasikan alasan dan mengomunikasikan gagasan yang dimilikinya kepada orang lain (Herlina, dkk, 2013). Hasilnya, pada tahun 2019 kemampuan matematis siswa di Indonesia berada pada peringkat ke-73 dari 79 negara yang tercatat dalam PISA.

Selain fakta di atas, penelitian awal untuk mengukur kemampuan komunikasi matematis siswa di SMA Negeri 1 Depok menunjukkan sebanyak 38,23\% siswa mendapat nilai antara 0-25 dengan kategori kurang dan 38,23\% siswa mendapat nilai antara 26-50 dengan kategori cukup. Selain itu, 17,64\% siswa mendapat nilai antara 51-75 dengan kategori baik, dan sisanya 8,82\% siswa mendapat nilai 76-100 dengan kategori sangat baik. Hasil tes awal kemampuan komunikasi matematis ini menunjukkan kategori kurang dan cukup lebih mendominasi dibanding kategori baik dan sangat baik.

Berdasarkan penjabaran di atas, terdapat kesenjangan antara kemampuan komunikasi yang dianggap penting dengan kenyataan pencapaiannya yang masih rendah. Salah satu penyebab rendahnya kemampuan komunikasi yang perlu menjadi perhatian adalah sajian pembelajaran matematika yang masih menggunakan pembelajaran konvensional. Hal ini berhubungan dengan pengelolaan kelas yang dilakukan oleh guru saat mengajar matematika. Abdullah dan Suratno (2015), dalam penelitiannya menyebutkan bahwa pengembangan kemampuan komunikasi matematis berhubungan dengan strategi pembelajaran yang dipilih guru. Guru bebas untuk menentukan model dan pendekatan yang digunakan dalam pembelajaran matematika di kelas. Pemilihan model dan pendekatan dalam pembelajaran matematika harus disesuaikan dengan kondisi yang sedang berlangsung, baik dari segi waktu, tempat, dan keadaan. 
Kondisi yang terjadi di Indonesia pada awal Maret 2020 adalah masuknya wabah virus SARSCoV-2 atau yang lebih dikenal dengan virus korona yang berasal dari Negara Tiongkok. Virus korona menyebabkan penyakit yang membahayakan yang dikenal dengan nama COVID-19. Virus korona semakin menyebar ke banyak orang dan wilayah di Indonesia sehingga berdampak ke berbagai bidang, termasuk bidang pendidikan. Pada tanggal 15 Maret 2020, di Istana Bogor, Jawa Barat, melalui pidatonya Presiden Republik Indonesia mengambil kebijakan agar sekolah-sekolah melaksanakan pembelajaran dari rumah. Kebijakan ini ditindaklanjuti dengan aturan masing-masing pemimpin daerah untuk meliburkan sekolah tatap muka dan menggantinya dengan Pembelajaran Jarak Jauh (PJJ).

Kondisi yang telah dijabarkan di atas menuntut guru dan siswa untuk mampu melaksanakan Pembelajaran Jarak Jauh (PJJ) dengan baik. Menurut Munir (2009), pembelajaran jarak jauh dirancang untuk mengatasi batasan jarak, tempat, waktu dalam melaksanakan proses pembelajaran. Munir (2009) menjelaskan bahwa pembelajaran jarak jauh adalah proses pembelajaran dengan tidak terjadinya kontak dalam bentuk tatap muka langsung antara guru dan siswa. Komunikasi pada pembelajaran jarak jauh berlangsung dua arah yang dijembatani dengan media seperti komputer, televisi, radio, telepon, internet, video dan sebagainya.

Pembelajaran jarak jauh dapat dilaksanakan dengan menerapkan suatu pendekatan pembelajaran tertentu. Pendekatan yang digunakan dalam pembelajaran matematika bertujuan agar lebih mendukung berkembangnya kemampuan komunikasi matematis siswa. Salah satu pendekatan yang dapat digunakan adalah pendekatan pembelajaran kontekstual. Menurut Suhartini dan Santoso (2014) pembelajaran kontekstual memiliki ciri yaitu berpusat pada siswa. Hal ini sesuai dengan keadaan yang mengharuskan pembelajaran jarak jauh di mana guru tidak dapat menjadi pusat pembelajaran secara utuh karena adanya kendala jarak.

Pembelajaran dengan pendekatan kontekstual dilaksanakan dengan memperhatikan kemampuan siswa, alat pendukung pembelajaran, situasi dan kondisi, serta memperhatikan tujuan pembelajaran yang ingin dicapai. Pendekatan kontekstual akan memudahkan siswa menghubungkan materi yang disampaikan ke dalam pengetahuannya tentang permasalahan nyata dalam kehidupan sehari-hari. Siswa akan terlatih menerjemahkan kondisi nyata yang terjadi ke dalam sebuah model matematika untuk dipecahkan. Oleh karena itu, pendekatan kontekstual yang diterapkan di dalam pembelajaran jarak jauh diharapkan mampu meningkatkan kemampuan komunikasi matematis siswa.

Belum ada penelitian yang membahas hubungan antara pendekatan kontekstual yang dilakukan pada pembelajaran jarak jauh dengan kemampuan komunikasi matematis siswa. Oleh karena itu, dilaksanakannya pendekatan kontekstual pada pembelajaran jarak jauh menjadi kebaruan dalam penelitian dan menunjukkan pentingnya penelitian yang akan dilakukan. Berdasarkan uraian di atas, penelitian yang akan dilakukan berjudul "Pengaruh Pendekatan Kontekstual pada Pembelajaran Jarak Jauh Terhadap Kemampuan Komunikasi Matematis Siswa SMA Negeri 1 Depok". Penelitian ini penting untuk dilakukan sehubungan dengan pembelajaran jarak jauh yang sednag banyak digunakan akibat adanya pandemi. Dengan adanya penelitian ini, diharapkan dapat memberikan masukan kepada guru-guru yang ingin memvariasikan pembelajaran jarak jauh menggunakan pendekatan pembelajaran.

\section{METODE}

Metode yang digunakan dalam penelitian ini adalah metode eksperimen semu dengan desain penelitian Posttest-Only Control Group Desain. Populasi terjangkau pada penelitian ini adalah siswa kelas X SMA Negeri 1 Depok tahun ajaran 2019/2020. Teknik pengambilan sampel menggunakan Two Stage Sampling, yaitu Purposive Sampling dan Cluster Random Sampling. Tahap pertama Purposive Sampling, terpilih 3 kelas yang termasuk ke dalam jurusan IPA dengan guru matematika yang sama. Tahap kedua adalah Cluster Random Sampling, yaitu pengambilan 2 dari 3 kelas yang telah lolos uji prasyarat analisis data sebelum perlakuan. Satu kelas sebagai kelas eksperimen dengan 35 siswa (X IPA 4) yang belajar menggunakan pembelajaran jarak jauh dengan pendekatan kontekstual dan satu kelas sebagai kelas kontrol dengan 32 siswa (X IPA 6) yang belajar menggunakan model pembelajaran konvensional.

Instrumen penelitian yang digunakan adalah instrumen tes kemampuan komunikasi matematis pada materi Trigonometri. Tes ini berupa tujuh soal uraian yang telah diuji validitas dan reliabilitasnya. 
Berikut contoh soal yang digunakan dalam penelitian:

TABEL 1. Soal Instrumen Tes Kemampuan Komunikasi Matematis

\begin{tabular}{|c|c|}
\hline Indikator soal & Soal \\
\hline $\begin{array}{l}\text { - Menentukan nilai perbandingan } \\
\text { trigonometri (sinus, cosinus, tangen, } \\
\text { cosecan, secan, atau cotangen) pada } \\
\text { segitiga siku-siku }\end{array}$ & $\begin{array}{l}\text { Segitiga PQR siku-siku di Q dengan panjang } \\
\mathrm{PQ}=2 \mathrm{~cm} \text { dan } \mathrm{QR}=\sqrt{5} \mathrm{~cm} . \\
\text { a. Gambarlah segitiga } \mathrm{PQR} \text { beserta } \\
\text { keterangan ukurannya! } \\
\text { b. Tentukanlah nilai sin } R !\end{array}$ \\
\hline $\begin{array}{l}\text { - Membuat model matematika dari } \\
\text { masalah yang berkaitan dengan } \\
\text { perbandingan trigonometri pada segitiga } \\
\text { siku-siku } \\
\text { - Menyelesaikan masalah perbandingan } \\
\text { trigonometri dengan mengukur tinggi } \\
\text { sebuah menara }\end{array}$ & $\begin{array}{l}\text { Seorang anak berdiri di depan sebuah } \\
\text { menara pada jarak } 30 \text { meter. Jika sudut yang } \\
\text { terbentuk antara pijakan anak di tanah } \\
\text { dengan puncak menara adalah } 30^{\circ} \text {, maka... } \\
\text { a. Gambarkan ilustrasi soal lengkap } \\
\text { dengan semua informasinya! } \\
\text { b. Hitunglah tinggi menara! }\end{array}$ \\
\hline
\end{tabular}

Hasil uji validitas instrumen tes dapat dilihat pada Tabel 2 berikut:

TABEL 2. Hasil Uji Validitas Instrumen Tes

\begin{tabular}{|c|c|c|c|c|}
\hline Soal & $\boldsymbol{r}_{\boldsymbol{x y}}$ & Keterangan & Kesimpulan & Katagori \\
\hline 1 & 0,560 & $r_{x y}>0,3$ & Valid & Cukup Baik \\
\hline 2 & 0,307 & $r_{x y}>0,3$ & Valid & Buruk \\
\hline 3 & 0,801 & $r_{x y}>0,3$ & Valid & Baik \\
\hline 4 & 0,609 & $r_{x y}>0,3$ & Valid & Cukup Baik \\
\hline 5 & 0,692 & $r_{x y}>0,3$ & Valid & Cukup Baik \\
\hline 6 & 0,831 & $r_{x y}>0,3$ & Valid & Baik \\
\hline 7 & 0,704 & $r_{x y}>0,3$ & Valid & Baik \\
\hline 8 & 0,744 & $r_{x y}>0,3$ & Valid & Baik \\
\hline
\end{tabular}

Hasil perhitungan reliabilitas tes kemampuan komunikasi matematis yang terdiri dari tujuh butir soal, diperoleh koefisien reliabilitas instrumen $\left(r_{11}\right)$ sebesar 0,8241 , hal ini menunjukkan bahwa $0,80<$ $r 11 \leq 1,00$ sehingga intrumen penelitian dapat dikatakan reliabel dalam kategori sangat tinggi.

Teknik analisis data menggunakan uji-t untuk dua sampel independen dengan terlebih dahulu dilakukan uji normalitas dan homogenitas sesudah perlakuan. Selanjutnya dilakukan Uji Cohen's d untuk mengetahui besar pengaruh pendekatan kontekstual pada pembelajaran jarak jauh terhadap kemampuan komunikasi matematis siswa SMA Negeri 1 Depok.

\section{HASIL}

\section{Uji Prasyarat Analisis Data Sebelum Perlakuan}

Hasil uji normalitas sebelum perlakuan disajikan dalam Tabel 3.

TABEL 3. Hasil Uji Normalitas Sebelum Perlakuan

\begin{tabular}{|c|c|c|c|c|c|}
\hline Kelas & $\boldsymbol{L}_{\boldsymbol{o}}$ & $\boldsymbol{L}_{\text {tabel }}$ & Keterangan & Kesimpulan & Interpretasi \\
\hline X IPA 4 & 0,133 & 0,144 & $L_{o}<L_{\text {tabel }}$ & Terima $H_{0}$ & Normal \\
\hline X IPA 5 & 0,136 & 0,146 & $L_{o}<L_{\text {tabel }}$ & Terima $H_{0}$ & Normal \\
\hline
\end{tabular}




\begin{tabular}{|l|l|l|l|l|l|}
\hline X IPA 6 & 0,117 & 0,150 & $L_{o}<L_{\text {tabel }}$ & Terima $H_{0}$ & Normal \\
\hline
\end{tabular}

Berdasarkan Tabel 1, diketahui bahwa seluruh kelas yang diuji memiliki nilai $\quad$ Lo $<$ Ltabel, artinya keputusan terima $H_{0}$. Hal ini memberikan kesimpulan bahwa ketiga kelas yaitu X IPA 4, X IPA 5, dan X IPA 6 berdistribusi normal.

Hasil uji homogenitas sebelum perlakuan disajikan dalam Tabel 4.

TABEL 4. Hasil Uji Homogenitas Sebelum Perlakuan

\begin{tabular}{|c|c|c|}
\hline $\boldsymbol{X}^{\mathbf{2}}{ }_{\text {hitung }}$ & $\boldsymbol{X}^{\mathbf{2}}$ tabel & Interpretasi \\
\hline 0,135 & 5,991 & Homogen \\
\hline
\end{tabular}

Berdasarkan Tabel 2, diketahui bahwa nilai $X^{2}{ }_{\text {hitung }}<X^{2}$ tabel, artinya keputusan terima $H_{0}$. Hal ini memberikan kesimpulan bahwa ketiga kelas yaitu X IPA 4, X IPA 5, dan X IPA 6 memiliki varians yang sama atau homogen.

Hasil uji kesamaan rata-rata disajikan dalam Tabel 5.

TABEL 5. Hasil Uji Kesamaan Rata-rata

\begin{tabular}{|c|c|c|}
\hline $\boldsymbol{F}_{\text {hitung }}$ & $\boldsymbol{F}_{\text {tabel }}$ & Interpretasi \\
\hline 0,332 & 3,080 & Rata-rata sama \\
\hline
\end{tabular}

Berdasarkan Tabel 3, diketahui bahwa nilai $F_{\text {hitung }}<F_{\text {tabel }}$, artinya keputusan terima $H_{0}$. Hal ini memberikan kesimpulan bahwa ketiga kelas yaitu X IPA 4, X IPA 5, dan X IPA 6 memiliki kesamaan rata-rata. Kemudian, dari ketiga kelas tersebut terpilih kelas X IPA 4 sebagai kelas eksperimen, yaitu kelas yang memperoleh perlakuan berupa pendekatan kontekstual dalam pembelajaran jarak jauh dan kelas X IPA 6 sebagai kelas kontrol, yaitu kelas yang memperoleh perlakuan berupa model pembelajaran konvensional.

\section{Uji Prasyarat Analisis Data Setelah Perlakuan}

Hasil uji normalitas setelah perlakuan disajikan dalam Tabel 6.

TABEL 6. Hasil Uji Normalitas Setelah Perlakuan

\begin{tabular}{|c|c|c|c|c|c|}
\hline Kelas & $\boldsymbol{L}_{\boldsymbol{o}}$ & $\boldsymbol{L}_{\text {tabel }}$ & Keterangan & Kesimpulan & Interpretasi \\
\hline X IPA 4 & 0,115 & 0,150 & $L_{o}<L_{\text {tabel }}$ & Terima $H_{0}$ & Normal \\
\hline X IPA 6 & 0,076 & 0,157 & $L_{o}<L_{\text {tabel }}$ & Terima $H_{0}$ & Normal \\
\hline
\end{tabular}

Berdasarkan Tabel 4, diketahui bahwa kedua kelas yang diuji memiliki nilai $\quad$ Lo $<$ Ltabel, artinya keputusan terima $H_{0}$. Hal ini memberikan kesimpulan bahwa kedua kelas yaitu X IPA 4 dan X IPA 6 berdistribusi normal.

Hasil uji homogenitas sebelum perlakuan disajikan dalam Tabel 7.

TABEL 7. Hasil Uji Homogenitas Sebelum Perlakuan

\begin{tabular}{|c|c|c|}
\hline $\boldsymbol{X}^{\mathbf{2}}{ }_{\text {hitung }}$ & $\boldsymbol{X}^{\mathbf{2}}$ tabel & Interpretasi \\
\hline 1,728 & 2,003 & Homogen \\
\hline
\end{tabular}


Berdasarkan Tabel 5, diketahui bahwa nilai $F_{\text {hitung }}<F_{\text {tabel }}=F_{0.025(31,34)}$, artinya keputusan terima $H_{0}$. Hal ini memberikan kesimpulan bahwa kelas eksperimen dan kelas kontrol memiliki varians yang sama atau homogen.

\section{Uji Analisis Data}

Hasil uji kesamaan rata-rata disajikan dalam Tabel 8.

TABEL 8. Hasil Uji-t Dua Sampel Independen

\begin{tabular}{|c|c|c|}
\hline $\boldsymbol{t}_{\text {hitung }}$ & $\boldsymbol{t}_{\text {tabel }}$ & Kesimpulan \\
\hline 6,753 & 1,668 & Tolak $H_{0}$ \\
\hline
\end{tabular}

Berdasarkan Tabel 6, diketahui bahwa nilai $t_{\text {hitung }}>t_{\text {tabel }}$, artinya keputusan tolak $H_{0}$. Hal ini memberikan kesimpulan bahwa rata-rata skor tes kemampuan komunikasi matematis siswa kelas eksperimen lebih tinggi dibandingkan dengan rata-rata skor tes kemampuan komunikasi matematis siswa kelas kontrol.

\section{Uji Besar Pengaruh}

Hasil uji besar pengaruh disajikan dalam Tabel 9.

TABEL 9. Hasil Uji Cohen's d

\begin{tabular}{|c|c|c|}
\hline d & Kategori & Persentase \\
\hline 1,6 & Large/Besar & $94,5 \%$ \\
\hline
\end{tabular}

Berdasarkan Tabel 7, dapat disimpulkan bahwa besar pengaruh dari penerapan pendekatan kontekstual pada pembelajaran jarak jauh terhadap kemampuan komunikasi matematis siswa adalah sebesar 94,5\% dan termasuk ke dalam kategori pengaruh yang besar.

\section{PEMBAHASAN}

Rata-rata kemampuan komunikasi matematis siswa kelas eksperimen sebesar 86,472, lebih tinggi dari kelas kontrol yaitu sebesar 72,816 pada materi trigonometri. Hal ini disebabkan oleh adanya perbedaan kegiatan pembelajaran pada kedua kelas tersebut. Kelas eksperimen belajar dengan pendekatan kontekstual pada pembelajaran jarak jauh, sedangkan kelas kontrol belajar dengan model pembelajaran konvensional.

Pendekatan kontekstual pada pembelajaran jarak jauh di kelas eksperimen dilakukan dengan setidaknya sepuluh langkah. Kegiatan pembukaan pembelajaran dilakukan oleh guru melalui aplikasi Google Classroom, dilanjutkan dengan penyampaian tujuan pembelajaran yang dicapai. Hal ini sebagai bentuk penerapan prinsip pendekatan kontekstual, yaitu konstruktivisme. Siswa mendapatkan gambaran tentang materi pembelajaran dan tujuannya dalam kehidupan sehari-hari, kemudian membangun keterkaitannya. Tahap ini memudahkan siswa dalam mengekspresikan ide matematis, yaitu mengidentifikasi unsur yang diketahui dan ditanyakan pada masalah kemampuan komunikasi matematis yang diberikan.

Selanjutnya guru menyampaikan motivasi, apersepsi, dan membuka tanya jawab tentang materi prasyarat. Pada beberapa pertemuan, tahap ini juga dilakukan dengan memberikan link video tentang materi prasyarat. Hal ini membantu siswa kembali mengingat materi yang sebelumnya dipelajari, terutama materi yang berkaitan dengan materi baru yang akan dipelajari. Tahap ini juga mendukung prinsip pendekatan kontekstual pada bagian konstruktivisme, sehingga memudahkan siswa mengekspresikan ide matematis. 
Kegiatan inti pembelajaran diawali dengan penyampaian materi dan contoh masalah oleh guru. Hal ini dilakukan dengan berbagai cara pada pertemuan yang berbeda-beda seperti menggunakan rekaman audio, video yang sudah dibuat oleh guru sebelumnya, atau menggunakan aplikasi tatap muka secara online seperti aplikasi Zoom Meeting. Tahap ini termasuk ke dalam prinsip pendekatan kontekstual yaitu pemodelan dan menemukan. Berdasarkan pengalaman pada pelaksanaan pembelajaran, siswa menjadi lebih mudah dalam menggambarkan situasi masalah ke dalam bentuk visual dan melakukan perhitungan berdasarkan situasi masalah dan ide matematis. Hal ini karena siswa sudah mendapatkan pemodelan dari guru sebelumnya.

Kegiatan pembelajaran dilanjutkan dengan guru mendemonstrasikan penyelesaian suatu masalah. Hal ini sedikit berbeda dengan tahap sebelumnya. Jika sebelumnya guru memberi penjelasan materi dan contoh masalah, pada tahap ini guru mendemonstrasikan penyelesaian masalah dari awal hingga akhir. Tahap ini membantu siswa melanjutkan perhitungan, menyatakan hasil dengan benar, dan memahami hasil perhitungan ke dalam suatu interpretasi matematika tertulis.

Tahap pembelajaran jarak jauh dengan pendekatan kontekstual selanjutnya adalah guru membagi siswa ke dalam beberapa kelompok. Kelompok tersebut terdiri dari siswa yang heterogen agar terjalin diskusi pada saat pengerjaan Lembar Kerja Kelompok (LKK). Walaupun pengerjaan LKK dilakukan melalui aplikasi WhatsApp, namun pada pelaksanaannya diskusi dan pembagian tugas tetap berjalan dengan cukup baik. Diskusi kelompok yang dilakukan sebagai prinsip masyarakat belajar pada pendekatan kontekstual berdampak positif terhadap kemampuan siswa menemukan langkah-langkah efektif dalam penyelesaian masalah. Tahap ini juga menjadi sarana guru melakukan penilaian yang sebenarnya, karena guru ikut memantau jalannya diskusi di WhatsApp Group.

Setelah diskusi berjalan dan masalah yang diberikan dalam bentuk LKK sudah diselesikan, tahap selanjutnya guru meminta perwakilan kelompok untuk menjelaskan hasil diskusinya melalui Google Classroom. Namun, pada kenyataannya tahap ini tidak berjalan dengan baik karena terkendala waktu dan juga teknis penjelasan yang kurang efektif. Hal ini dapat diatasi oleh guru dengan tetap me-review tahapan penyelesaian masalah yang diberikan. Selanjutnya guru memberikan tes berupa soal yang berhubungan dengan materi yang dipelajari. Hal ini membantu siswa mengingat kembali seluruh tahapan penyelesaian masalah, yang juga merupakan indikator kemampuan komunikasi matematis.

Pembelajaran pada kelas eksperimen diakhiri dengan merangkum pembelajaran dan memberikan arahan terkait dengan materi yang akan dipelajari pada pertemuan selanjutnya. Dengan demikian, siswa akan lebih siap dalam mempelajari materi yang akan datang. Tahapan pembelajaran jarak jauh dengan pendekatan kontekstual yang telah dijelaskan, seluruhnya dirancang agar dapat mendukung kemampuan komunikasi matematis siswa.

Hal berbeda diterapkan pada kelas kontrol yang belajar dengan model pembelajaran konvensional. Pembelajaran konvensional yang dimaksud adalah pembelajaran jarak jauh dengan cara yang biasa dilakukan oleh guru tanpa arahan apapun dari peneliti. Tahap awal pembelajaran ini adalah membuka pelajaran melalui aplikasi Google Classroom. Guru menyampaikan tujuan pembelajaran yang ingin dicapai dan memberikan motivasi belajar kepada siswa. Pada tahap ini, siswa merespons guru dengan menjawab salam dan menyambut motivasi yang diberikan oleh guru.

Langkah berikutnya adalah guru menyampaikan materi dan memberikan contoh baik melalui rekaman audio, video, atau menggunakan aplikasi tatap muka seperti Zoom Meeting. Tahap ini dilakukan dengan kesepakatan bersama siswa sehingga berbeda penerapannya pada tiap pertemuan. Namun, pada pelaksanaannya, tahap ini kurang mendapat respons yang baik dari siswa. Hal ini terlihat dari tidak adanya jawaban siswa pada saat guru membuka diskusi.

Selanjutnya guru memberikan soal-soal latihan kepada siswa secara bertingkat. Mulai dari latihan tahap awal dengan soal yang mudah yang dikerjakan bersama guru atau disebut juga latihan terstruktur, sampai kepada latihan mandiri dengan soal-soal yang lebih sulit. Guru memberikan batas waktu pengerjaan kepada siswa. Sayangnya, siswa di kelas kontrol juga kurang antusias dan banyak diantaranya yang mengumpulkan latihan soal di luar batas yang ditentukan. Hal ini mengakibatkan tahap yang semestinya dilakukan setelah latihan soal yaitu presentasi atau diskusi melalui Google Classroom tidak berjalan dengan baik. Tahap terakhir pada pembelajaran konvensional di kelas kontrol adalah guru memberikan tugas lanjutan kepada siswa untuk dikerjakan dan dibahas pada pertemuan berikutnya. 
Berdasarkan penjelasan di atas, dapat diketahui bahwa beberapa perbedaan yang nampak pada kedua kelas adalah langkah-langkah pembelajaran, peran guru dan siswa, serta antusias siswa dalam pembelajaran. Oleh karena itu, wajar jika rata-rata kemampuan komunikasi matematis kelas eksperimen lebih tinggi dari kelas kontrol. Dengan demikian, terdapat pengaruh signifikan dari pendekatan kontekstual pada pembelajaran jarak jauh terhadap kemampuan komunikasi matematis siswa SMA Negeri 1 Depok pada pokok bahasan trigonometri dengan taraf signifikansi $\propto=0,05$.

Hasil penelitian ini sesuai dengan hasil penelitian relevan yang telah dilakukan sebelumnya, seperti Penelitian yang dilakukan oleh Bernard menunjukkan bahwa pencapaian dan peningkatan kemampuan komunikasi matematik siswa dengan pendekatan kontekstual melalui Game Adobe Flash CS 4.0 lebih baik dibandingkan dengan pembelajaran cara biasa (Bernard, 2015). Selain itu juga penelitian yang dilakukan oleh Nuriadin menunjukkan bahwa pendekatan kontekstual berbantuan program Geometer's Sketchpad memberikan pengaruh positif yang signifikan terhadap kemampuan komunikasi dan koneksi matematis siswa SMP (Nuriadin, 2015).

\section{PENUTUP}

\section{Kesimpulan}

Berdasarkan rumusan masalah, hasil analisis data, dan pembahasan yang telah diuraikan pada bab sebelumnya, didapat nilai $t_{\text {hitung }}=6,753$ dan $t_{\text {tabel }}=1,668$. Hal ini menunjukkan bahwa rata-rata kemampuan komunikasi matematis siswa SMA Negeri 1 Depok yang belajar menggunakan pendekatan kontekstual lebih tinggi daripada rata-rata kemampuan komunikasi matematis siswa yang belajar dengan menggunakan model pembelajaran konvensional berupa pembelajaran jarak jauh pada pokok bahasan Trigonometri. Selain itu, dapat disimpulkan bahwa pendekatan kontekstual pada pembelajaran jarak jauh memiliki pengaruh signifikan sebesar 94,5\% terhadap kemampuan komunikasi matematis siswa SMA Negeri 1 Depok.

Beberapa hal yang direkomendasikan untuk peneliti selanjutnya adalah melakukan perluasan terhadap penelitian ini. Seperti melakukan di sekolah yang jangkauannya lebih luas, melakukan penelitian pada materi yang berbeda, memperpanjang masa pembelajaran, serta melakukan perbaikanperbaikan teknis berdasarkan penelitian yang sudah dilakukan.

\section{REFERENSI}

Abdullah, I. H., \& Suratno, J. (2015). Pengaruh Pendekatan Pembelajaran Masalah Terhadap Kemampuan Komunikasi Matematis Siswa. Jurnal Pengajaran MIPA, 20(2), 112-115. https://doi.org/http://dx.doi.org/10.18269/jpmipa.v20i2.572

Azmi, M. P. (2017). Asosiasi Antara Kemampuan Analogi Dengan Komunikasi Matematik Siswa SMP. Al-Jabar : Jurnal Pendidikan Matematika, 8(1), 91. https://doi.org/10.24042/ajpm.v8i1.902

Bernard, M. (2015). Meningkatkan Kemampuan Komunikasi Dan Penalaran Serta Disposisi Matematik Siswa Smk Dengan Pendekatan Kontekstual Melalui Game Adobe Flash Cs 4.0. Infinity Journal, 4(2), 197. https://doi.org/10.22460/infinity.v4i2.84

Fatmasuci, F. W. (2017). Pengembangan perangkat pembelajaran berbasis masalah berorientasi pada kemampuan komunikasi dan prestasi belajar matematika siswa SMP. Jurnal Riset Pendidikan Matematika, 4(1), 32. https://doi.org/10.21831/jrpm.v4i1.11325

Herlina, S., Turmudi, \& Dahlan, J. A. (2012). Efektivitas strategi REACT dalam upaya peningkatan kemampuan komunikasi matematis. Jurnal Pengajaran MIPA, 17(1), 1-7

Mahmud, D. A., \& Hartono, H. (2014). Keefektifan Model Pembelajaran Isk Dan Di Ditinjau Dari 
Motivasi, Sikap, Dan Kemampuan Komunikasi Matematis. Jurnal Riset Pendidikan Matematika, 1(2), 188. https://doi.org/10.21831/jrpm.v1i2.2675

Munir. (2009). Pembelajaran jarak jauh berbasis teknologi informasi dan komunikasi. Bandung: Alfabeta.

National Council of Teacher of Mathematics [NCTM]. (2000). Executive Summary Principles and Standards for School Mathematics. [Online].Tersedia: http://www.nctm.org

Nuriadin, I. (2015). Pembelajaran Kontekstual Berbantuan Program Geometer'S Sketchpad Dalam Meningkatkan Kemampuan Koneksi Dan Komunikasi Matematis Siswa Smp. Infinity Journal, 4(2), 168. https://doi.org/10.22460/infinity.v4i2.80

Suhartini, S., \& Santoso, R. H. (2014). Pengembangan Perangkat Pembelajaran Matematika Untuk Siswa Smk Jurusan Akuntansi Di Sleman Dengan Pendekatan Pembelajaran Kontekstual. Jurnal Riset Pendidikan Matematika, 1(1), 69. https://doi.org/10.21831/jrpm.v1i1.2665

Suriasumantri, Jujun S. (2015). Filsafat Ilmu: Sebuah Pengantar Populer. Jakarta: Pustaka Sinar Harapan. 